\title{
The Role of Social Support in the Family Resilience in COVID-19 Pandemic
}

\author{
Diah Rahayu $^{1}$, Lisda Sofia ${ }^{2}$, Meirinja Raudatul Jannah ${ }^{3}$ \\ Program Studi Psikologi, Fakultas Ilmu Sosial dan Ilmu Politik Universitas Mulawarman, \\ Samarinda, Indonesia ${ }^{1,2,3}$ \\ \{rahayudiah77@gmail.com ${ }^{1}$, lisda.sofia@fisip.unmul.ac.id² ${ }^{2}$
}

\begin{abstract}
The COVID-19 pandemic swept the world and changed the society structural order, including the smallest one, which was family. According to data from the World Health Organization (WHO), many countries reported the increase of domestic violence cases during the pandemic. This was assumed to be caused by the policy of home-quarantine in order to sever the spread of COVID-19, resulting in the increase of the intensity of domestic violence. Data from the national commission for women and children also strengthened the assumption. This was also followed by the increase of numbers of divorce in families. Based on this condition, this research aimed to answer several important questions regarding family resilience during the pandemic. Including how big the role of social support on family resilience was and which source of social support had the biggest affect on family resilience level in the pandemic. This research was conducted in Samarinda, using quantitative methods on 317 research subjects. Descriptively, $66.5 \%$ of family resilience in Samarinda was still considered to be high. The results of regression analysis with beta score $=$ 0.542 and $p=0.000(p<0.05)$ indicated that social support could predict family resilience. The $\mathrm{R}$ square $=0.292$ showed that the role of social support to family resilience was as big as $29.2 \%$. Social support from the environment and close friends was more dominant compared to from extended family and other important figures such as counsellor or psychologists.
\end{abstract}

Keywords: Family Resilience; Social Support; COVID-19 Pandemic

\section{Introduction}

The world, including Indonesia, was facing the COVID-19 pandemic. The COVID-19 pandemic was a new pandemic caused by a new virus in the virus group of SARS and MERS. Concern related to this virus pandemic was caused by its massive spread and difficulty in predicting the symptoms, being similar to fly symptoms but with fatal results. This affected the government policy. In Indonesia, the president announced the Massive Scale Social Distancing (Pembatasan Sosial Berskala Besar [PSBB]) policy, based on the UU No. 6 Tahun 2018 regarding quarantine. This policy aimed to prevent the spread of emergency related to community health diseases from a particular area. This policy included stopping the activities 
of schools, universities, and work, making people work from home, live cleanly and healtily, use face masks, wash hands, reduce the intensity of going out, and area quarantine [1].

The implementation of efforts to sever the spread of the pandemic affected social order, one of it being the obligation of quarantine. Area quarantine and home quarantine may be a moment of togetherness with family members for a part of the society, but it was not the same for all families, as several cases reported that the condition increased household conflict or domestic violence. Limitations of social life for weeks or even months, in particular onditions, may result in uncertainty and fear for many individuals, couples, and families. This condition became the catalyst for higher levels of domestic violence and divorce. Women and children were most susceptible to become victims.

According to data from the World Health Organization (WHO), many countries reported the increase of domestic violence cases, including in Samarinda, East Kalimantan, Indonesia. Based on the data collected online by the Demography and National Family Planning Agency (Badan Kependudukan dan Keluarga Berencana Nasional [BKKBN]) on more than 20,000 families, $95 \%$ of families were reported to be stressed from the pandemic and social distancing. This was collected on April-May of 2020. The data from the National Women Commission during the pandemic until April 17 showed 204 cases of violence on women via e-mail, 268 cases via phone, and 62 cases via mail. This condition was followed by the high case of divorce, impacting women and children the most. This portrayed the existence of problem regarding family resilience.

Due to the current situation and condition, it was important for families to be relisient in handling the pandemic. Kristiyani [2] stated that family resilience had become very relevant, especially in facing the COVID-19 pandemic. Family resilience explained about a family capable of functioning as a place of love, safety, protection, support, despite facing a stressor causing the family to experience pressure, problems, or conflict in a situation such as the COVID-19 pandemic [3]. This concept was initially developed by Ruther as cited by Black and Lobo [4] from studying the positive adaptation of children during uncomfortable situations such as when being pressed [4], later on further developed into application on learning the family system $[5,6]$. Family resilience to rearch family stability as a whole was stated as a concept chaining the line of thought in a system. This system stated from the quality of the resource of coping strategy, and the value of individuals in the family. Later on, family resilience was considered to be an adaptation strategy towards challenges to psychological well-being [7].

The COVID-19 pandemic could affect various aspects in the family system. Family unpreparedness in facing the pandemic would result in stress, triggering the coping and adaptation strategy in each individual in the family. This ability to adapt was a form of defense for the family, where the family able to overcoming it would become a strong family. Cutrona as cited by Irzalinda et al. [8] stated that social support was one of the many factors affecting family adaptive coping. Friedemann as cited by Irzalinda et al. [8] stated that the existence of social support was the main external coping strategy for families.

The appropriate social support could help families in fulfilling their needs during difficult situations, finding effecting methods to solve problems, feeling loved and valued, resulting in the increase in self-efficacy and capability for better life [9]. The experienced social support would make individuals more capable in adapting to difficult conditions, eventually resulting in family resilience [10].

Social support in the form of helping fellow family members was proven to be effective in becoming the main factor in society to be more resilient in their coping towards stressful condition, resulting in society becoming strengthened in facing the pandemic (Lazarus as cited 
by Perdana [11]). Social support would increase self-concept, self-identity, motivation, selfefficacy, and optimism as the main elements in the process of resilience (Gottlieb \& Heller as cited by Perdana [11]). Society with strong support in both economy and social would be more capable in facing problems. According to Cutrona et al. as cited by Irzalinda et al. [8], social support experienced by families supported their efforts in solving problems post-pandemic. Therefore, this research would conduct a more in-depth review on the role of social support on family resilience. Whether social support still affected the increase of family resilience during the COVID-19 pandemic. This was caused by the massive uncertainty experienced by each individual during the pandemic, resulting in them focusing on their own conditions and families. This research would focus on the role of social support as the main interest.

\section{Methodology}

\subsection{Participants}

The participants of this research were married adults with the age range of 25-65 years of age, living in Samarinda, East Kalimantan. The number of participants in this research was 316 people, $24 \%$ being males and $76 \%$ being females, with the education level of doctoral (4\%), magister (24\%), bachelor and diploma (54\%), high school (15\%), and below high school (3\%).

\subsection{Measurement}

Participants were requested to fill the Family Resilience Assessment Scale (FRAS) questionnaire which consisted of 48 items with three measurement aspects, being belief system (Making Meaning of Adversity, Positive Outlook, Transcendence and Spirituality), family organizational patterns (Flexibility, Connectedness Social and Economic Resources), and communication processes or problem solving (Clarity, Open Emotional Expression, Collaborative Problem Solving). Social support was measured using the Multidimensional Scale of Perceived Social Support which consisted of 12 items with the measurement aspects of family support, friend support, and support from others deemed to be proficient in helping. Results of the reliability testing is available in Table 1 .

Table 1 showed that the instruments used in this research had good reliability scores as the scores were higher than 0.70 , meaning that the instruments were capable in measureming the research variables.

Table 1. Instrument Reliability $(\mathrm{N}=317)$

\begin{tabular}{cc}
\hline Variable & Alpha \\
\hline Family Resilience & 0.963 \\
Social Support & 0.889 \\
\hline
\end{tabular}

\subsection{Data Analysis}

Quantitative data analysis was conducted using regression analysis, in order to discover the level of influence of social support on family resilience. Regression analysis results is available in Table 2. Based on Table 2, it was discovered that beta $=0.542$ and $p=0.000(p<$ 0.05 ), showing that social support was able to predict family resilience. The score of $\mathrm{R}$ square $=0.292$ showed the effectiveness of social support on family resilience being $29.2 \%$. This data 
showed that social support had significant effects on family resilience, despite it only being $29.2 \%$. The rest of $70.8 \%$ was affected by variables other than social support.

Table 2. Results of the Regression Analysis Hypotheses Testing

\begin{tabular}{cccccc}
\hline Variable & $\mathbf{R}^{2}$ & Beta & T calculation & T table & P \\
\hline Social Support $(\mathrm{X})$ & 0.292 & 0.542 & 11.334 & 1.968 & 0.000 \\
Family Resilience (Y) & & & & & \\
\hline
\end{tabular}

\section{Results and Discussion}

This research discussed the role of social support on family resilience during the COVID19 pandemic in Samarinda. Research results showed that social support had positive relationship with family resilience. This meant that the higher the social support, the higher the family resilience. Therefore, social support had a significant role on family resilience during the COVID-19 pandemic.

The concept of family resilience explained how a family understand and maximize their potential in order to face problems and pressure, especially during the COVID-19 pandemic [3]. Family also had a significant role in facing the COVID-19 pandemic, observable from the function of family as a source of protection, keeping the family healthy by reminding each other regarding self-care such as hand-washing and the culture of being healthy and clean. The second function was providing love by ensuring comfort and attention, especially to keep emotional stability in order to keep being "happy" during the COVID-19 pandemic [12].

During the pandemic, family resilience showcased uniqueness where family either became broken or stronger and wiser because of the constant pressure from the pandemic [3]. This statement was in accordance with the research results, available from the categorization of family resilience, showing that $65.9 \%$ of the research subjects had high family resilience. High family resilience was obtained from being capable of implementing family strategies while facing pressure, problem, or conflict during the COVID-19 pandemic. The success of the strategy depended on how the families value the currently faced problem [3].

The strategy to face crisis during the COVID-19 pandemic must be supported by resources such as: positive emotion such as love, humor, optimism, positive solution, and suggestion to strengthen one another in order to make the family healthier [3]. Having a healthy family during the COVID-19 pandemic or even in the new normal would be extremely important. A healthy family would not only result in social support from the community, but also returning the support to the community. A wide system of social support from the family and extended family could interact reciprocally in providing information and contribution to family wellbeing [13].

The previous explanation was supported by a previous research [14] which stated that social support had an effect on family resilient, meaning that social support had a role in family resilience. Social support often focused on the structural size of social relationship, the size of structural network, or on the size of functional perception of individuals on available support or experienced support. Initial study measured social support by measuring and reviewing social relationship, such as marital status, church attendance, and number of close friends. Social support could be utilized as resource from others, especially family and friends, and could be divided into sub-types of functional support such as emotional, informative, and instrumental supports (Dunkel-Schetter et al. as cited by Harvey \& Alexander [15]). For example, emotional support which consisted of love and care - often from spouse, family 
memebrs, and close trusted people. This could make individuals feel loved, and therefore motivating health-related behaviors and increasing family resilience during the COVID-19 pandemic.

In the partial analysis, it was discovered that family support, friend support, and support from others had relationship with one of the aspects of family resilience, which was belief system. Family support, friend support, and support from others could help family members in managing and facing crisis situations such as during COVID-19 pandemic. Family support experienced was in the form of positive view, such as with friend support and support from others, providing support in facing adversities, usually possessed by optimistic and hopeful for the future families. This would help families in overcoming the adversities by believing in the family belief system.

The family belief system managed their experience and helped them in how family members could understand the situation, events, and behavior in their environment [5]. This showcased the importance of family support, friend support, and support from others in increasing family resilience during the COVID-19 pandemic. Family support also had a role in the communication process and communication was important in increasing the family function and resilience.

In the second partial analysis, family support, friend support, and support from others also had relationship with family organizational patterns. The need for family support, friend support, and support from others was formed in creating the organization process. This meant that this process was a pattern in creating flexibility. A resilient family would be able to adapt to adverse situations and conditions [5].

In the third partial analysis, family support, friend support, and support from others had a relationship with the communication process. The availability of harmonious communication was the core of how families create meaningful togetherness, develop strategy for countermeasures, and maintain agreements and balance [3]. Walsh [5] stated that there were three important aspects in family communications in order to increase family resilience, which was clarity, open emotional expression, and problem solving. The development of effective communication so families could, in synergy, solve problems. Effective communication involved speaking for themselves and not for others, listening with empathy and attention, and also sharing about one's self and the relationships with other parties [5].

Based on the previous explanation, it could be concluded that social support had a role in family resilience during the COVID-19 pandemic. Also, each aspect of social support, such as family support, friend support, and support from others also had the role in increasing family resilience.

\section{Conclusion}

This study found that family resilience in East Kalimantan, especially in the city of Samarinda, was generally quite good even in the pandemic conditions. This is different from the data which states that the level of domestic violence and divorce is an indication of the weak resilience of families in Indonesia. One of the factors influencing this condition is social support from the circle of friends and the assistance of experts if the family feels they need help related to problems in the household. However, social support from the family environment still an important role in fostering strength and harmony in the family. The hope is that Indonesian families will have family resilience in order to creat a strong generation to sustain the country's resilience. Social support is one of the important factors so that with the 
distinctive Indonesian motto "gotong Royong " and "tepo seliro" it is hoped that the Indonesian people will continue to have sympathy and empathy between families to strengthen each other.

\section{Acknowledgements}

The writers would like to thank to the Psychology Department of Faculty of Social and Political Science of Universitas Mulawarman Samarinda.

\section{References}

[1] Setiawan, S. N., \& Nurwati, N.: Dampak COVID-19 terhadap tenaga kerja di Indonesia tenaga kerja di Indonesia. Research Gate, Vol. 1(1), pp. 1-21 (2020).

[2] Kristiyani, V.: Membangun resiliensi keluarga ketika menghadapi wabah Covid-19 (2020, April).

[3] Herdiana, I.: Resiliensi keluarga: Teori, aplikasi dan riset. Proceeding National Conference Psikologi UMG (2018).

[4] Black, K., \& Lobo, M.: A conceptual review of family resilience factors. Journal of Family Nursing, Vol. 14(1), pp. 33-55 (2008).

[5] Walsh, F.: Special section family resiliance : A concept and its application the concept of family resilience : Crisis and challenge. Family Process, Vol. 35, pp. 1-14 (1996).

[6] Walsh, F.: A family resilience framework: Innovative practice applications. Family Relation, Vol. 51, pp. 130-137 (2002).

[7] Mawarpury, M., \& Mirza.: Resiliensi dalam keluarga: perspektif psikologi. Jurnal

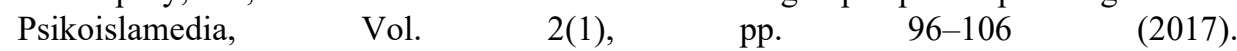
https://doi.org/10.22373/psikoislamedia.v2i1.1829

[8] Irzalinda, V., Sofia, A., Guru, P., Anak, P., Dini, U., \& Lampung, U.: Pengaruh koping strategi terhadap resilience keluarga rawan bencana abstrak. Jurnal Obsesi: Jurnal Pendidikan Anak Usia Dini, Vol. 4(1), pp. 201-210 (2020). https://doi.org/10.31004/obsesi.v4i1.312

[9] Raisa, \& Ediati, A.: Hubungan antara dukungan sosial dengan resiliensi pada narapidana di lembaga pemasyarakatan kelas II A wanita Semarang. Empati, Vol. 5(3), pp. 537-542 (2016).

[10] Jannah, S. N., \& Rohmatun.: Hubungan antara dukungan sosial dengan resiliensi pada penyintas banjir Rob tambak Lorok. Jurnal Proyeksi, Vol. 13(1), pp. 1-12 (2018). https://doi.org/10.1017/CBO9781107415324.004

[11] Perdana.: Dukungan sosial di masa korona. Radar Solo, p. 1 (2020).

[12] Susilowati, E.: Covid-19 pandemi dalam banyak wajah. PT. Raja Grafindo Persada (2020).

[13] Luthar, S. S., Cicchetti, D., \& Becker, B.: The construct of resilience: A critical evaluation and guidelines for future work, Vol. 71(3), pp. 543-562 (2000).

[14] Poegoeh, D. P., \& Hamidah.: Peran dukungan sosial dan regulasi emosi terhadap resiliensi keluarga penderita skizofrenia. Insan Jurnal Psikologi Dan Kesehatan Mental, Vol. 1(1), pp. 11-21 (2016).

[15] Harvey, I. S., \& Alexander, K.: Perceived social support and preventive health behavioral outcomes among older women. Journal of Cross-Cultural Gerontology ,Vol. 27(3), pp. 275-290 (2012). 